\title{
Pharmacogenetics of antidepressant response: An update
}

Antonio Drago, Diana De Ronchi and Alessandro Serretti*

Institute of Psychiatry, University of Bologna, Bologna, Viale Carlo Pepoli 5, 40123 Bologna, Italy

*Correspondence to: Tel: +39 51 6584233; Fax: +39 51 521030; E-mail: alessandro.serretti@unibo.it

Date received (in revised form): 14 January 2009

\begin{abstract}
The past few decades have witnessed much progress in the field of pharmacogenetics. The identification of the genetic background that regulates the antidepressant response has benefited from these advances. This review focuses on the pharmacogenetics of the antidepressant response through the analysis and discussion of the most compelling evidence in this line of research. Online databases (Medline and PsycINFO) have been searched and the most replicated association findings relating to the genetics of the antidepressant response have been reported and discussed. Some replicated findings in the literature have suggested the serotonin transporter promoter (5-HTTLPR), serotonin receptor IA (HTRIA), serotonin receptor 2A (HTR2A), brain derived neurotrophic factor (BDNF), corticotropin releasing hormone receptor I (CRHRI) and FK506 binding protein 5 (FKBP5) as putative regulators of the antidepressant response. A high rate of failure of replication has also been reported.

Pharmacogenetics will hopefully provide the basis for personalised antidepressant treatment that is able to maximise the probability of a good response and to minimise side effects; however, this goal is not achievable at the moment. The extent of the validity of the replicated findings and the reasons for the poor results obtained from studies of the pharmacogenetics of the antidepressant response are discussed.
\end{abstract}

Keywords: pharmacogenetics, gene, antidepressant response, association study, candidate, genome-wide association

\section{Introduction}

Pharmacogenetics investigates how genes impact the response to drugs, both in terms of efficacy and side effects. The aim of this field of research is to define a set of genetic variations which is able to predict the response to drugs. If achieved, this result may lead to a revolution of sorts, given that antidepressant treatment is currently prescribed on a trial and error principle that exposes patients to a higher risk of failure, a worsening of symptoms and side effects. Moreover, a large proportion of patients do not benefit from antidepressant drug therapies: ${ }^{1}$ the response rate is estimated at $55-75$ per cent, ${ }^{2}$ while full remission is achieved by one-third of patients after a trial with adequate dose ranges. ${ }^{3}$ Hopefully, genetic counselling will give the opportunity to tailor the right treatment to a specific patient, providing a higher probability of a good antidepressant response. In this review, the background and the current level of knowledge about the pharmacogenetics of antidepressant response is presented and discussed.

\section{Pharmacogenetics}

Different biological events, as diverse as absorption, distribution, target interaction, biotransformation and excretion, take place when a drug is administered. The interaction between these events gives rise to the global drug response. A number of systems are involved in these mechanisms 
(absorption involves the gastroenteric system, distribution involves systems such as the brain-blood barrier, and so on), so a large number of genes is likely to be involved in these complex processes. As a consequence, the drug response is not a Mendelian trait, and is not ruled by the one geneone phenotype principle. Instead, a polygenic background is hypothesised. Under this condition, a single mutation in one gene intuitively is likely to have a small impact. As an example, a single gene variant was observed to have an effect of about 5 per cent on antidepressant activity. ${ }^{4}$ Moreover, the impact of a single variant is not simply additive to the effect of the other variants, but can enhance, counteract or modify the functional relevance of other variants by the means of reciprocal interactions. Finally, gene, environmental and psychological variables together impact the phenomenology of complex traits (such as a drug response) and interact with the genes in ways that are still incompletely understood. ${ }^{5}$ In conclusion, the extent of the impact of a single gene on drug response depends on interactions between genetic, environmental and psychological factors. Within these limits, there is still some evidence that key mutations, located in specific genes, may be responsible for a considerable proportion of the variance in a drug response. These mutations are the object of this paper. Consistent with this, there is strong evidence that the response to antidepressant treatment is an inheritable trait: Angst ${ }^{6}$ reported that 28 out of 41 first-degree relative pairs on imipramine treatment were concordant with regard to the antidepressant response. Pare and colleagues ${ }^{7}$ consistently reported that relatives of depressed patients treated with the same antidepressant drug had equivalent responses, with an overall rate of response rate of 42 per cent. A new cohort studied by the same group ${ }^{8}$ found that ten out of 12 patients with concordant antidepressant treatment were concordant for clinical response. These data are consistent with the results of a retrospective study ${ }^{9}$ in which four out of eight members of the same family suffering from depressive disorders, who were resistant to tricyclic antidepressants (TCAs), all responded to monoamine oxidase
(MAO) inhibitor treatment. Finally, a study ${ }^{10}$ investigated 45 first-degree relative pairs who had been treated with fluvoxamine for at least six weeks and found a concordance rate of 67 per cent for response, replicating a previous paper on TCAs. ${ }^{11}$ The number of genes that has been investigated so far can be grouped according to their independent replication rate. Candidate genes with more than two independent replications may be considered as putative relevant factors. In this paper, the candidate genes that had a high number of replicated findings are reported and discussed. We here define 'replication' as the presence of at least two independent studies that detected a concordant signal of significant association for the same set of genetic variations for the same variation with regard to the antidepressant response. This definition does not rule out the possibility of a type-1 error, since it does not account for differences in study design or sample size, possible stratification factors and differences in the power of studies.

\section{Evidence}

\section{Pharmacokinetics}

Even though the background of pharmacogenetics is complex, there are some replicated results that allow a certain cautious optimism, especially with regard to pharmacokinetics. It has been demonstrated convincingly that the general population can be divided into fast drug metabolisers, very fast drug metabolisers and slow drug metabolisers on the basis mainly of genetic variations in cytochrome P450 (CYP) 1A, CYP2A6, CYP2B6, CYP2C, CYP2D6, CYP2E1 and CYP3A. This topic has been extensively reviewed in recent works, ${ }^{1}$ and the evidence is so consistent that private organisations and public institutions have started to genotype the major variations in these enzymes. In the absence of a genetic approach, blood sampling is a valid means of checking the concentration of a drug in the blood of individual patients. The relevance of these variations is limited by the fact that it has been demonstrated that the therapeutic efficacy of antidepressant treatments is not strictly dependent on the concentration of the drug in 
blood. $^{12}$ Knowledge of the genotype of pharmacokinetics-related mutations, however, may play a pivotal role in special populations of patients at risk of serious side effects as a result of concomitant treatments or concomitant diseases, in whom blood sampling may be an inappropriate strategy. An example of such a case is when a patient at risk of an arrhythmia needs to undergo treatment with an antidepressant, as reviewed recently. ${ }^{13}$ In this situation there is a direct interaction between blood drug concentration and the degree of interference of the drug with the depolarisationrepolarisation phases of the heart. It would be helpful to know in advance if the patient is a poor metaboliser of the antidepressant that is going to be administered in order to avoid potentially fatal side effects. In addition, recent findings highlighted another pharmacokinetics-related candidate: $\mathrm{P}$ glycoprotein, which is a product of the $A B C B 1$ gene. $\mathrm{P}$ glycoprotein exerts its activity by regulating drug transition through cell membranes. $\mathrm{P}$ glycoprotein is expressed in the brain-blood barrier and its activity regulates the ability of antidepressants to reach neurones. Consistent with this, a number of antidepressant treatments have been shown to be targets for this enzyme or to impact its functioning. An important association investigation in the context of the STAR*D study, by Peters et al., ${ }^{14}$ failed to detect an association between a set of mutations located in a list of pharmacokinetics genes that also included $A B C B 1$. The drug under study was citalopram, and the investigated sample was theoretically large enough to limit the possibility of false-positive or negative findings $(1,877$ subjects). ${ }^{14}$ Nevertheless, it should be noted that these authors selected a set of 15 variations located in all the genes under study. $A B C B 1$ alone shows 525 validated single nucleotide polymorphisms (SNPs), of which nine are not synonymous (http:// www.ncbi.nlm.nih.gov/). Conflicting with the results of Peters et al., ${ }^{14}$ positive association findings were reported ${ }^{15}$ and have since been replicated. ${ }^{16}$

Overall, the analysis of pharmacokinetics-related genes has not yet had a dramatic impact on everyday clinical experience with depressed patients, considering that the main use of such techniques is limited to a special population of patients who are particularly at risk of side effects (Tables 1 and 2).

Some inconsistent results have been reported for catechol-O-methyl transferase (COMT), one of several enzymes that degrade catecholamines such as dopamine, epinephrine and norepinephrine. Results are reported in Table 3.

\section{Pharmacodynamics: The serotonin system}

One of the main targets of antidepressant drugs is the serotonin transporter; its biological role is to clear the intrasynaptic neuronal space by reabsorbing serotonin into presynaptic neurones. It is believed that antidepressants exert their activity, at least partially, by enhancing the serotonin concentration in the neuronal cleft through the inhibition of serotonin intake. This action is thought to be associated with enhanced serotonergic tone, which results in a downregulation of serotonin receptors after a period of two or three weeks, an event that may be relevant to the elevation of mood. This has been convincingly demonstrated in animal models $^{27}$ and imaging studies in humans. ${ }^{28}$ Consistent with this, one of the most replicated findings in this field is the association between the short/long allele at the promoter of the serotonin transporter and the response to antidepressant drug treatment. The long allele of the promoter is characterised by an enhanced expression rate. Carriers of this allele were found to benefit from a higher density of serotonin transporters on the surface of their neurones, which may be related to a more antidepressant drug-responsive serotonergic system, given that the serotonin transporter is the putative key target of the antidepressant effect. ${ }^{29}$ This has been fairly consistently reported in the literature, although this association appears to be more consistent in Caucasian samples. This may be related to one of the following possibilities: the different frequencies of the short/long allele in different ethnicities; an intricate set of confounding factors that may be related to a different genetic orchestration at the level of signal transduction; a differently modulated response to diverse environmental factors; and different study designs 
Table I. Relevant pharmacogenetics association studies that have focused on cytochrome P450 (CYP)

\begin{tabular}{|c|c|c|c|c|c|c|}
\hline Reference & Gene & Drug & Sample & $\begin{array}{l}\text { Outcome } \\
\text { measure(s) }\end{array}$ & Results & $p$-value \\
\hline (I7) & CYP2B6 & Bupropion & $\begin{array}{l}\text { 29I patients } \\
\text { treated with } \\
\text { bupropion } \\
\text { or placebo } \\
\text { (12 weeks) }\end{array}$ & $\begin{array}{l}\text { Abstinence } \\
\text { rates }\end{array}$ & $\begin{array}{l}\text { Individuals with the } \\
\text { DRD2-Taql A2/A2 } \\
\text { genotype demonstrated } \\
\text { a higher odds ratio of } \\
\text { abstinence only if they } \\
\text { possessed the CYP2B6 } \\
\text { I } 459 \text { T/T or C/T } \\
\text { genotypes }\end{array}$ & $p<0.01$ \\
\hline (18) & $\begin{array}{l}\text { CYP2D6 } \\
\text { and } \\
\text { CYP2CI9 }\end{array}$ & Amitriptyline & $\begin{array}{l}202 \\
\text { post-mortem } \\
\text { cases of } \\
\text { patients } \\
\text { receiving } \\
\text { treatment } \\
\text { with } \\
\text { amitriptyline }\end{array}$ & $\begin{array}{l}\text { Plasma } \\
\text { concentration } \\
\text { of amitriptyline } \\
\text { and of six } \\
\text { metabolites }\end{array}$ & $\begin{array}{l}\text { Positive correlations } \\
\text { between } \\
\text { trans-hydroxylated } \\
\text { metabolites and number } \\
\text { of functional copies of } \\
\text { CYP2D6 and between } \\
\text { demethylated } \\
\text { metabolites and the } \\
\text { number of functional } \\
\text { copies of CYP2CI9 }\end{array}$ & $0.026<p<0.001$ \\
\hline (19) & CYP2D6 & Venlafaxine & 100 patients & CGI UKU & $\begin{array}{l}\text { A PM phenotype of } \\
\text { CYP2D6 increases } \\
\text { the risk of side effects, } \\
\text { especially when } \\
\text { O-desmethylvenlafaxine/ } \\
\text { venlafaxine ratios } \\
\text { below } 0.3\end{array}$ & $p<0.005$ \\
\hline (20) & CYP2D6 & Fluvoxamine & $\begin{array}{l}100 \\
\text { depressed } \\
\text { outpatients }\end{array}$ & $\begin{array}{l}\text { Clinical } \\
\text { assessment of } \\
\text { Gl side effects }\end{array}$ & $\begin{array}{l}\text { CYP2D6 PM with G/G } \\
\text { 5-HT2A A-I438G } \\
\text { polymorphism had } \\
4.242 \text {-fold higher risk of } \\
\text { GI side effects and PM } \\
\text { with the A/G genotype } \\
\text { had a } 4.147 \text {-fold higher } \\
\text { risk of Gl side effects }\end{array}$ & $\begin{array}{l}p=0.009 \text { and } \\
p=0.004\end{array}$ \\
\hline (2I) & $\begin{array}{l}\text { CYP2C9, } \\
2 C 19 \\
\text { and 2D6 }\end{array}$ & $\begin{array}{l}\text { Amitriptyline, } \\
\text { citalopram, } \\
\text { clomipramine, } \\
\text { doxepin, } \\
\text { fluvoxamine, } \\
\text { mirtazapine, } \\
\text { paroxetine, } \\
\text { sertraline and } \\
\text { venlafaxine }\end{array}$ & $\begin{array}{l}136 \\
\text { depressed } \\
\text { Caucasian } \\
\text { patients }\end{array}$ & $\begin{array}{l}\text { HAMD } \\
\text { CGI } \\
\text { UKU }\end{array}$ & $\begin{array}{l}\text { Significant influence of } \\
\text { the CYP2D6 genotype, } \\
\text { minor influence of the } \\
\text { CYP2CI9 genotype and } \\
\text { no influence of the } \\
\text { CYP2C9 genotype on } \\
\text { plasma antidepressant } \\
\text { concentrations. No } \\
\text { association between } \\
\text { plasma concentration } \\
\text { and antidepressant } \\
\text { response }\end{array}$ & $p<0.001$ \\
\hline
\end{tabular}


Table I. Continued

\begin{tabular}{|c|c|c|c|c|c|c|}
\hline Reference & Gene & Drug & Sample & $\begin{array}{l}\text { Outcome } \\
\text { measure(s) }\end{array}$ & Results & $p$-value \\
\hline$(22)$ & CYP2D6 & Various & $\begin{array}{l}200 \\
\text { outpatients } \\
\text { enrolled, } 28 \\
\text { were eligible } \\
\text { for analysis }\end{array}$ & $\begin{array}{l}\text { Presence of } \\
\text { adverse effects }\end{array}$ & $\begin{array}{l}\text { PM associated with } \\
\text { more side effects; UM } \\
\text { genotype is associated } \\
\text { with non-responder } \\
\text { phenotype }\end{array}$ & $\begin{array}{l}p<0.001 \text { and } \\
p=0.0012\end{array}$ \\
\hline
\end{tabular}

Abbreviations: GI, gastrointestinal; HAMD, Hamilton Rating Scale for Depression; CGI, Clinical Global Impression; UKU, Udvalg for Kliniske Undersogelser Side Effect Rating Scale; PM, poor metaboliser; UM, ?!?.

Table 2. Relative pharmacogenetics studies that have focused on $\mathrm{P}$ glycoprotein

\begin{tabular}{|c|c|c|c|c|c|c|}
\hline Reference & Gene & Drug & Sample & $\begin{array}{l}\text { Outcome } \\
\text { measure }\end{array}$ & Results & $p$-value \\
\hline (16) & $\begin{array}{l}P \\
\text { glycoprotein }\end{array}$ & Various & $\begin{array}{l}443 \\
\text { inpatients }\end{array}$ & HAMD & $\begin{array}{l}\text { The following } \\
\text { variations were } \\
\text { associated with } \\
\text { remission after six } \\
\text { weeks of treatment: } \\
\text { rs } 2235067 \\
\text { rs } 4 \text { I } 48740 \\
\text { rs } 1028010 \text { I } \\
\text { rs } 7787082 \\
\text { rs } 2032583 \\
\text { rs } 4 \text { I } 48739 \\
\text { rs I } 1983225 \\
\text { rs } 10248420 \\
\text { rs } 2235040 \\
\text { rs } 12720067 \\
\text { rs } 2235015\end{array}$ & $\begin{array}{l}* 0.0011 \\
0.00015 \\
0.00029 \\
0.0025 \\
0.00027 \\
0.00015 \\
0.00022 \\
0.0025 \\
0.0015 \\
0.000092 \\
0.0024\end{array}$ \\
\hline (23) & $\begin{array}{l}P \\
\text { glycoprotein }\end{array}$ & Nortriptyline & $\begin{array}{l}160 \\
\text { patients }\end{array}$ & $\begin{array}{l}\text { Postural } \\
\text { hypotension }\end{array}$ & $\begin{array}{l}\text { The } 3435 \mathrm{C}>\mathrm{T} \\
\text { (rs I045642) variation } \\
\text { was associated with } \\
\text { a higher risk of } \\
\text { nortriptyline-induced } \\
\text { postural hypotension. }\end{array}$ & $p=0.034$ \\
\hline
\end{tabular}

(characteristics of the samples, recruiting methods for controls etc). The evidence associating the short/long allele with a range of side effects is more sparse, ${ }^{30}$ and a couple of interesting papers reported that the short allele is associated with a better response to antidepressant treatment when an augmentation strategy with pindolol and lithium is chosen. ${ }^{31}$ In this regard, it has been suggested that this gene-drug interaction may be related to the ability of lithium to increase the density of serotonin reuptake sites, ${ }^{32}$ so that the lithium-induced increased density of serotonin transporter activity may balance the genetic background associated with the short allele. ${ }^{31}$ Another explanation may be related to the ability of lithium, and also of pindolol, to inhibit the activity of serotonin receptor $1 \mathrm{~A}$, which is located pre- and post-synaptically and physiologically plays an inhibitory role. Given that 
Table 3. Relevant pharmacogenetics association studies that have focused on catechol-O-methyl transferase (COMT)

\begin{tabular}{|c|c|c|c|c|c|c|}
\hline Reference & Gene & Drug & Sample & $\begin{array}{l}\text { Outcome } \\
\text { measure }\end{array}$ & Results & $p$-value \\
\hline (24) & COMT & Bupropion & $\begin{array}{l}553 \\
\text { smokers }\end{array}$ & $\begin{array}{l}\text { Weight gain } \\
\text { after } \\
\text { smoking } \\
\text { cessation }\end{array}$ & $\begin{array}{l}\text { TC genotype at } \\
\text { the C } 957 T \\
\text { locus was } \\
\text { associated with } \\
\text { increased } \\
\text { weight gain at } \\
\text { six months of } \\
\text { follow-up; } \\
\text { however, no } \\
\text { polymorphisms, } \\
\text { or their } \\
\text { interactions } \\
\text { with bupropion, } \\
\text { consistently and } \\
\text { significantly } \\
\text { predicted } \\
\text { baseline BMI or } \\
\text { weight change }\end{array}$ & $\begin{array}{l}\text { Not } \\
\text { significant }\end{array}$ \\
\hline (25) & COMT & Various & $\begin{array}{l}346 \\
\text { MDD } \\
\text { patients }\end{array}$ & HAMD & $\begin{array}{l}\text { There was a } \\
\text { small effect with } \\
\text { citalopram } \\
\text { treatment } \\
\text { (Val(I08/ } \\
\text { I58)Met) }\end{array}$ & $\begin{array}{l}p=0.007 \\
\text { (gene per } \\
\text { time } \\
\text { interaction) }\end{array}$ \\
\hline (26) & COMT & $\begin{array}{l}\text { Mirtazapine } \\
\text { and } \\
\text { paroxetine }\end{array}$ & $\begin{array}{l}102 \\
\text { MDD } \\
\text { patients }\end{array}$ & HAMD & $\begin{array}{l}\text { COMT } \\
\text { polymorphism } \\
\text { Val(I08/I58)Met } \\
\text { influenced } \\
\text { mirtazapine but } \\
\text { not paroxetine } \\
\text { response }\end{array}$ & $p=0.011$ \\
\hline
\end{tabular}

Abbreviations: MDD, major depressive disorder; BMI, body mass index; COMT, catechol-O-methyl transferase; HAMD, Hamilton Rating Scale for Depression

the short allele corresponds to minor expression of the serotonin transporter in the synaptic cleft, individuals with the short allele will have a higher serotonin concentration in their synaptic cleft. This could result in hyperactivity of serotonin $1 \mathrm{~A}$ receptors, which could then lead to long-term deactivation of serotonergic transmission. This may explain the less favourable response in patients with this genetic variant when they are treated with serotonergic antidepressants. ${ }^{33}$ Lithium and pindolol may balance this genetic condition by limiting the activation of serotonin receptor $1 \mathrm{~A}$. Overall, this association between the short allele and a worse response to antidepressant treatment is currently one of the best pieces of evidence in the pharmacogenetics of antidepressants. Nonetheless, the classification into short and long alleles is an oversimplification because the presence of mutations within the repeated sequences that form the short and the long allele gives rise to a series of rare mutations which may impact transcription rates. ${ }^{34}$ For example, it has recently been demonstrated that only the A allele carriers at the A/G SNP within the long 5-HTTLPR insertion polymorphism 
yield high mRNA levels, and the long $+G$ carriers actually behave like the low-expressing short allele. $^{35}$ Other variations within the serotonin transporter gene have also attracted researchers' attention. One of the most investigated is the so-called Stin 2, a 17 bp variable number tandem repeats (VNTR) polymorphism within intron 2. This variation has been shown to impact on the antidepressant response, an association that was found to be more consistently replicated in Asian samples. $^{36}$ A lack of association has also been reported, however, ${ }^{37}$ so no definitive conclusions can be drawn at present. There are at least three other genes associated with the serotonin system, variations of which have been associated with the antidepressant response. These genes code for serotonin receptor $1 \mathrm{~A}$, serotonin receptor $2 \mathrm{~A}$ and tryptophan hydroxylase (TPH). As mentioned, serotonin receptor $1 \mathrm{~A}$ plays a pivotal role in the serotonin system, as it is involved in inhibitory circuits that are both pre- and post-synaptic. Intuitively, it is likely that variations within the genetic framework associated with this receptor have a profound impact on the modulation of the serotonin system. ${ }^{38}$ Serotonin receptor $2 \mathrm{~A}$ is one of the main effectors of the serotonin system; it triggers a molecular cascade, which has an excitatory effect on the post-synaptic neurones. ${ }^{39}$ Finally, TPH catalyses the rate-limiting step in serotonin biosynthesis. With regard to the antidepressant response, desensitisation of the serotonin 1A receptors located in the raphe nuclei is thought to be associated with the effect of serotonergic antidepressants, as demonstrated in animal and imaging studies, ${ }^{40}$ although a role for an increase in post-synaptic activity of serotonin 1A receptors has recently been demonstrated. $^{41}$ Interestingly, the serotonin receptor $1 \mathrm{~A}$ transcription rate is modulated by a mutation in the upstream regulatory region, C(1019)G (rs6295). Allele $\mathrm{G}$ is associated with a weak interaction with repressors Deaf1 and Hes5; its presence abolishes Deaf1 action and impairs Hes5 action, leading to upregulation of genetic expression. ${ }^{42}$ This functional polymorphism has been associated with the antidepressant response, and the $\mathrm{C}$ allele (the allele which is associated with downregulation of expression of the serotonin receptor $1 \mathrm{~A}$, which is believed to happen after medium-term antidepressant treatment) was found to be associated with a better response to antidepressant treatment. ${ }^{43}$ Negative association studies have also been published. ${ }^{44}$ There are various explanations to account for this discrepancy. Firstly, the antidepressant response is the consequence of intricate interactions between a multitude of genes and environmental factors, the latter being time dependent, ${ }^{45}$ so that the genetic basis for the response to antidepressant treatment may be population specific and time specific. Moreover, Levin and colleagues' negative association study ${ }^{44}$ was probably underpowered to detect a difference between responders and nonresponders because of an imbalance between cases (responders; $n=100$ ) and controls (nonresponders; $n=33$ ). Moreover, the study was designed to be retrospective, and was thus sensitive to 'recall bias', and did not use a tag approach. Further, four out of seven investigated variations showed no variability in responders. Finally, covariate analysis included only gender and the number of SNPs, but many other factors (sociodemographic, life events related and psychological) may impact the response to treatment. The study published by Arias and colleagues ${ }^{46}$ in 2005 analysed a limited number of patients $(n=130)$, and so was probably underpowered to detect the small impact of a single variation. Even though they found an association when combining the variation at serotonin receptor $1 \mathrm{~A}$ and the serotonin transporter, the levels of significance $(p=0.02 ; p=0.009)$ have been demonstrated to be prone to a high frequency of false-positive findings. ${ }^{47}$ Moreover, a complete analysis of the variations located in a specific gene was not conducted, thereby exposing the study to a relevant genetic stratification factor because it did not take into account the possible impact of genetic variables located close to the one under investigation. Limited sample sizes $(n=96$ in the study by Peters and colleagues in $2004 ;^{48} n=100$ in the study by Suzuki in $2006^{20}$ ) may be responsible for the absence of an association. The positive association studies that suggested a role for $\mathrm{C}(1019) \mathrm{G}$ (rs6295) in the antidepressant response 
suffer from a similar limitation, so that a type-1 error remains a concern, which is only partially solved by the independent replication rate. ${ }^{38}$ Three variations within the coding region of the serotonin receptor 2A (HTR2A, 5HT2A) have been implicated in the antidepressant response: 5HT2A $\mathrm{T}(102) \mathrm{C}, \quad 5 \mathrm{HT} 2 \mathrm{~A}$ G(1438)A and 5HT2A C(1420)T. 5HT2A T(102)C and 5HT2A G(1438)A are two of the most investigated variations of this gene; they are in linkage disequilibrium (LD), and they can be considered together. ${ }^{49}$ With regard to antidepressant treatment, it has been reported that the $\mathrm{C}$ allele at variation $\mathrm{T}(102) \mathrm{C}$ (or the $\mathrm{G}$ allele at variation $G(1438) A$, which is the same) are associated with a more pronounced effect on antidepressant treatment, both in terms of mood elevation and of side effect profile. ${ }^{50}$ Again, lack of association has also been reported, ${ }^{51}$ the reasons for which may depend on the same factors that have been discussed for the serotonin receptor 1A. The association between the $\mathrm{T}(102) \mathrm{C} \mathrm{C}$ allele and the antidepressant response suggests that the $\mathrm{C}$ allele, which has been associated with a lower expression rate of the receptor in some studies, ${ }^{39}$ is also associated with a better prognosis in terms of antidepressant effect. This association is not surprising because serotonin receptor $2 \mathrm{~A}$ is involved in an auto-inhibiting the short circuit involved in GABAergic interneurones. ${ }^{39}$ The downregulation of serotonin receptors, which is possibly associated with the pharmacodynamics of antidepressant drugs, ${ }^{52}$ is likely to be more pronounced if the receptors are further downregulated as a result of genetic control. There are two main isoforms of $\mathrm{TPH}$, isoform 1 and isoform 2. In the adult brain, isoform 2 is expressed at higher rates, while isoform 1 plays an important role during brain development. ${ }^{53}$ The main replicated findings for these genes as regulators of antidepressant pharmacogenetics were reported for the A218C variant of isoform 1, which is located in a potential galactitolspecific phosphotransferase enzyme IIA (GATA) transcription factor binding site, and this genetic mutation was reported to influence gene transcription; the rarer $\mathrm{TPH} 1 *$ a allele has been reported to be associated with decreased serotonin synthesis. ${ }^{54}$
Genetic studies that investigated the association between the A218C variant and the antidepressant response reported that the $\mathrm{A}$ allele was associated with a worse or slower response. If an association between a slower expression rate of this enzyme and a slower response to antidepressant treatment can be demonstrated, this would fit the serotonergic model of depression. A developing brain that is forced to face a genetically driven diminished level of serotonin will possibly develop neuronal interactions that are less influenced by serotonin. Similarly, exposure to a substance that enhances the serotonin level may be associated with a blunted antidepressant effect. Interestingly, TPH isoform 2 has been demonstrated to be highly sensitive to antidepressants in terms of mRNA expression rates (Tables 3-6). ${ }^{77}$

\section{Other well replicated pharmacodynamic genes}

$G$ protein beta 3 subunit is one interesting candidate gene. $G$ proteins are mediators of signal cascades, and their great variability in terms of subunit composition and association with diverse molecular pathways, gives rise to the molecular diversity that allows the development of complex biological systems. A polymorphism (C825T, rs5443) was identified in exon 10 of the beta 3 subunit; the $\mathrm{T}$ allele of this mutation is associated with the occurrence of a splice variant that appears to be less active than the wild-type form, in terms of the modulation of ion channels and in forming heterodimers with other proteins. ${ }^{78}$ This variant was found to be associated with a better antidepressant response in a set of independent investigations. ${ }^{72}$ Intriguingly, Joyce and colleagues ${ }^{72}$ reported that age was a differential pharmacogenetic predictor of the antidepressant response to nortriptyline and fluoxetine, with younger individuals (less than 25 years old) being more sensitive to variations within the serotonin transporter, and older individuals (more than 25 years old) being more sensitive to variations within the $\mathrm{G}$ beta 3 genetic framework. The medium-sized sample $(n=169)$ and the study design (individuals were randomised either to fluoxetine or nortriptyline) add to the relevance of this result. 
Table 4. Relevant pharmacogenetics association studies that focused on tryptophan hydroxylase I and 2 (TPHI and TPH2)

\begin{tabular}{|c|c|c|c|c|c|c|}
\hline Reference & Gene & Drug & Sample & $\begin{array}{l}\text { Outcome } \\
\text { measure }\end{array}$ & Results & $p$-value \\
\hline (55) & TPHI & Citalopram & 105 subjects & HAMD & $\begin{array}{l}\text { The remission } \\
\text { rate was worse } \\
\text { in } A / A \text { and } A / C \\
\text { genotypes, even } \\
\text { though the } \\
\text { response rate } \\
\text { did not differ } \\
\text { between } \\
\text { genotypes }\end{array}$ & $p=0.017$ \\
\hline (56) & TPHI & Various & $\begin{array}{l}93 \text { MDD } \\
\text { patients and } \\
127 \text { controls }\end{array}$ & HAMD & $\begin{array}{l}\text { No association } \\
\text { either with } \\
\text { depressive } \\
\text { phenotype } \\
\text { or with } \\
\text { antidepressant } \\
\text { response }\end{array}$ & Not significant \\
\hline (57) & TPHI & $\begin{array}{l}\text { Fluvoxamine } \\
\text { or } \\
\text { paroxetine }\end{array}$ & $\begin{array}{l}221 \text { MDD } \\
\text { patients }\end{array}$ & HAMD & $\begin{array}{l}\text { Lack of } \\
\text { association }\end{array}$ & Not significant \\
\hline (48) & $\begin{array}{l}\text { TPHI, } \\
\text { TPH2 }\end{array}$ & Fluoxetine & $\begin{array}{l}96 \text { MDD } \\
\text { patients }\end{array}$ & CGI & $\begin{array}{l}\text { Three variations } \\
\text { within the TPHI } \\
\text { differentiated } \\
\text { responders from } \\
\text { non-responders. } \\
\text { Three variations } \\
\text { in the TPH2 } \\
\text { differentiated } \\
\text { responders from } \\
\text { specific and } \\
\text { non-specific (fast } \\
\text { antidepressant } \\
\text { onset and lack of } \\
\text { persistence) }\end{array}$ & $0.020<p<0.042$ \\
\hline (4) & TPHI & Fluvoxamine & $\begin{array}{l}217 \mathrm{MDD} \\
\text { patients }\end{array}$ & HAMD & $\begin{array}{l}\text { A/A genotype } \\
\text { was associated } \\
\text { with slower } \\
\text { response (no } \\
\text { pindolol) }\end{array}$ & $p=0.001$ \\
\hline (58) & TPHI & Paroxetine & $\begin{array}{l}\text { I2I MDD } \\
\text { patients }\end{array}$ & HAMD & $\begin{array}{l}\mathrm{A} / \mathrm{A} \text { and } \mathrm{A} / \mathrm{C} \\
\text { genotypes were } \\
\text { associated with } \\
\text { slower response } \\
\text { (no pindolol) }\end{array}$ & $p=0.005$ \\
\hline
\end{tabular}

Abbreviations: MDD, major depressive disorder; HAMD, Hamilton Rating Scale for Depression; CGI, Clinical Global Impression scale 
Table 5. Relevant pharmacogenetics association studies that focused on monoamine oxidase-A (MAO-A)

\begin{tabular}{|c|c|c|c|c|c|c|}
\hline Reference & Gene & Drug & Sample & $\begin{array}{l}\text { Outcome } \\
\text { measure }\end{array}$ & Results & $p$-value \\
\hline (59) & MAO-A & Various & $\begin{array}{l}\text { I } 34 \\
\text { nuclear } \\
\text { families } \\
\text { (probands } \\
\text { affected by } \\
\text { bipolar } \\
\text { ( } n=103 \text { ) } \\
\text { or major } \\
\text { depressive } \\
\text { ( } n=58 \text { ) } \\
\text { disorders) }\end{array}$ & $\begin{array}{l}\text { Transmission } \\
\text { disequilibrium } \\
\text { test }\end{array}$ & $\begin{array}{l}\text { No } \\
\text { association }\end{array}$ & Not significant \\
\hline (48) & MAO-A & Fluoxetine & $\begin{array}{l}96 \text { MDD } \\
\text { patients }\end{array}$ & CGI & $\begin{array}{l}\text { Significant } \\
\text { association }\end{array}$ & $0.03<p<0.05$ \\
\hline (60) & MAO-A & $\begin{array}{l}\text { Fluvoxamine, } \\
\text { paroxetine }\end{array}$ & $\begin{array}{l}248 \text { MDD } \\
195 \text { BPD }\end{array}$ & HAMD & $\begin{array}{l}\text { No } \\
\text { association }\end{array}$ & Not significant \\
\hline
\end{tabular}

Abbreviations: MDD, major depressive disorder; MAO-A, monoamine oxidase A; BPD, bipolar disorder; CGI, Clinical Global Impression Scale; HAMD, Hamilton Rating Scale for Depression

Another candidate gene is FK506 binding protein 5 (FKBP5), part of a heteromultimeric cytoplasmic complex with HSP90, HSP70 and steroid receptors. This subunit is thought to be a modulator of the affinity by which the cortisol receptor binds to its ligand. Changes in the cortisol balance and general dysfunction of the hypothalamicpituitary-adrenal (HPA) axis are found in many major depressive disorder (MDD) patients (up to 70 per cent) ${ }^{79}$ so a modulator of this system is likely to be implicated in the response to antidepressant treatment. There is some evidence for a significant association between mutations in the FKBP5 genetic code and the antidepressant response, ${ }^{80}$ although the results are still preliminary and a lack of association has also been reported. ${ }^{81}$ In the latter study, however, it should be noted that a fixed dose of fluoxetine was used ( $20 \mathrm{mg} /$ day), which may be too low a dose to benefit a depressed patient. This was demonstrated by the fact that only 54 out of 125 depressed patients (43 per cent) responded to fluoxetine in this study. Finally, the different ethnicity (Chinese in the study by Tsai and colleagues, ${ }^{81}$ and Caucasians in the positive studies) and the different sampling of patients may also account for the differences in the results that have been reported. It may be the case that the real reason for these differences has still not been identified, but that a variation in LD occurred in the studies that reported positive association. With LD patterns being different between different ethnicities, the variation in LD found in studies reporting a positive association might not have been detected in the study involving Chinese subjects. ${ }^{81}$

Another candidate gene is the corticotrophinreleasing hormone $(\mathrm{CRH})$ receptor 1 gene. An association between the rs242941 G/G genotype and the GAG haplotype at rs1876828, rs242939 and rs242941 and the fluoxetine therapeutic response has been detected, ${ }^{82}$ and neurotrophic factors are also considered to be good candidates for pharmacogenetic investigations. Among these, attention has been focused on brain-derived neurotrophic factor (BDNF), a neurotrophin involved in the processes of differentiation and neuronal resilience. One of the most investigated genetic variations within the $B D N F$ gene is $196 \mathrm{G} / \mathrm{A}$ (rs6265), which results in a Val66 to Met (V66M) change in the $5^{\prime}$-pro-region of the protein. ${ }^{83}$ It has been reported that this variation is associated with poorer episodic memory 
Table 6. Relevant pharmacogenetics association studies that focused on the serotonin transporter promoter (5HTTLPR)

\begin{tabular}{|c|c|c|c|c|c|c|}
\hline Reference & Gene & Drug & Sample & $\begin{array}{l}\text { Outcome } \\
\text { measure }\end{array}$ & Results & $p$-value \\
\hline (3I) & 5HTTLPR & $\begin{array}{l}\text { Lithium } \\
\text { augmentation }\end{array}$ & $\begin{array}{l}47 \text { lithium-treated } \\
\text { patients } \\
\text { I I } 4 \text { lithium-free } \\
\text { patients }\end{array}$ & HAMD & $\begin{array}{l}\text { Patients homozygous for } \\
\text { the short allele had a } \\
\text { more favourable response } \\
\text { compared with those who } \\
\text { were heterozygous }\end{array}$ & $p=0.0002$ \\
\hline$(6 I)$ & 5HTTLPR & Paroxetine & $\begin{array}{l}\text { I } 10 \text { elderly MDD } \\
\text { patients }\end{array}$ & HAMD & $\begin{array}{l}\text { Paroxetine concentrations } \\
\text { were correlated with } \\
\text { change in HAMD scores } \\
\text { after two weeks of } \\
\text { treatment in subjects with } \\
\text { the short allele (elderly } \\
\text { population) }\end{array}$ & $p<0.05$ \\
\hline$(50)$ & 5HTTLPR & Paroxetine & $\begin{array}{l}166 \text { depressed } \\
\text { patients }\end{array}$ & HAMD & $\begin{array}{l}\text { 5-HTTLPR short allele } \\
\text { homozygotes were } \\
\text { significantly associated } \\
\text { with both remission and } \\
\text { response. Unipolar } \\
\text { patients homozygous for } \\
\text { the SLC6A4 intron } 2 \\
\text { repeat polymorphism were } \\
\text { significantly associated } \\
\text { with lack of remission and } \\
\text { lack of response }\end{array}$ & $\begin{array}{l}\text { Remission } \\
p=0.04 \\
\text { Response } \\
p=0.02 \\
\text { Lack of remission } \\
p=0.02 \\
\text { Lack of response } \\
p=0.01\end{array}$ \\
\hline$(62)$ & 5HTTLPR & Various & $\begin{array}{l}190 \text { depressed } \\
\text { patients }\end{array}$ & HAMD & SLC6A4: no association & Not significant \\
\hline (35) & 5HTTLPR & Citalopram & $\begin{array}{l}\text { I } 775 \text { patients with } \\
\text { non-psychotic } \\
\text { depression } \\
\text { (STAR*D) }\end{array}$ & $\begin{array}{l}\text { Categorical } \\
\text { response and } \\
\text { remission at } \\
\text { HAMD, } \\
\text { tolerance, and } \\
\text { adverse effect } \\
\text { burden }\end{array}$ & $\begin{array}{l}\text { A significant association } \\
\text { between the } L(A) \text { allele } \\
\text { and adverse effect burden } \\
\text { was detected. } A \text { lesser } \\
\text { adverse effect burden was } \\
\text { associated with } L(A) L(A) \\
\text { genotype frequency }\end{array}$ & $\begin{array}{l}p=0.004 \text { (whole } \\
\text { sample) } \\
p=0.03 \\
\text { (Caucasians only) }\end{array}$ \\
\hline (63) & 5HTTLPR & $\begin{array}{l}\text { Fluoxetine or } \\
\text { sertraline or } \\
\text { nortriptyline }\end{array}$ & $\begin{array}{l}241 \text { depressed } \\
\text { patients }\end{array}$ & HAMD & $\begin{array}{l}\text { Short allele of the intron } 2 \\
\text { variation was associated } \\
\text { with better response; } \\
\text { short allele at the } \\
5 \text { HTTLPR was associated } \\
\text { with response }\end{array}$ & $\begin{array}{l}p<0.00 \text { I } \\
\text { (nortriptyline); } \\
p=0.006 \text { (SSRIs) }\end{array}$ \\
\hline (34) & 5HTTLPR & Fluvoxamine & $\begin{array}{l}228 \text { patients (with } \\
\text { either bipolar or } \\
\text { unipolar } \\
\text { depression) }\end{array}$ & HAMD & $\begin{array}{l}\text { Long }(\mathrm{I}) \text { variant associated } \\
\text { with better and faster } \\
\text { response; I6F } * I \rightarrow \text { partial } \\
\text { response, I6D } * \mathrm{I} \rightarrow \text { better } \\
\text { response than } 16 \mathrm{~A} * \mathrm{I}\end{array}$ & $p=0.047$ \\
\hline
\end{tabular}


Table 6. Continued

\begin{tabular}{|c|c|c|c|c|c|c|}
\hline Reference & Gene & Drug & Sample & $\begin{array}{l}\text { Outcome } \\
\text { measure }\end{array}$ & Results & $p$-value \\
\hline (64) & 5HTTLPR & Various & $\begin{array}{l}109 \text { patients with } \\
\text { major depression }\end{array}$ & DOTES & $\begin{array}{l}\text { HTT-VNTR 2.10/2.10 } \\
\text { associated with higher } \\
\text { frequency of side effects; } \\
\text { HTTLPR s/s associated } \\
\text { with higher frequency of } \\
\text { side effects }\end{array}$ & $p=0.00018$ \\
\hline (65) & 5HTTLPR & Fluoxetine & $\begin{array}{l}224 \text { depressed } \\
\text { patients }\end{array}$ & HAMD & $\begin{array}{l}5 \text { HTTLPR I/I associated } \\
\text { with a better response }\end{array}$ & $p<0.001$ \\
\hline (66) & 5HTTLPR & $\begin{array}{l}\text { Fluoxetine and } \\
\text { paroxetine }\end{array}$ & $\begin{array}{l}100 \text { depressed } \\
\text { patients }\end{array}$ & HAMD & $\begin{array}{l}\text { 5HTTLPR: long allele } \\
\text { associated with better } \\
\text { response }\end{array}$ & $p=0.015-0.042$ \\
\hline (46) & 5HTTLPR & Citalopram & $\begin{array}{l}130 \text { depressed } \\
\text { patients }\end{array}$ & HAMD & $\begin{array}{l}\text { S/S-G/G haplotype was } \\
\text { found among subjects who } \\
\text { did not reach remission }\end{array}$ & $p=0.009$ \\
\hline (67) & 5HTTLPR & Various & $\begin{array}{l}\text { I } 28 \text { patients with } \\
\text { bipolar disorder, } 93 \\
\text { patients with } \\
\text { unipolar disorder }\end{array}$ & HAMD & No association & Not significant \\
\hline (68) & 5HTTLPR & Milnacipram & $\begin{array}{l}96 \text { depressed } \\
\text { patients }\end{array}$ & MADRS & No association & Not significant \\
\hline (57) & 5HTTLPR & $\begin{array}{l}\text { Fluvoxamine or } \\
\text { paroxetine }\end{array}$ & $\begin{array}{l}220 \text { depressed } \\
\text { patients }\end{array}$ & HAMD & $\begin{array}{l}\text { SERT s/s associated with } \\
\text { poorer response to } \\
\text { treatment; TPH no } \\
\text { significant result }\end{array}$ & $p=0.034$ \\
\hline (69) & 5HTTLPR & $\begin{array}{l}\text { Long-term } \\
\text { antidepressant } \\
\text { treatment }\end{array}$ & $\begin{array}{l}\text { I } 28 \text { depressed } \\
\text { patients }\end{array}$ & CGI & $\begin{array}{l}\text { s/s genotype was } \\
\text { associated with poorer } \\
\text { outcome }\end{array}$ & $p=0.025$ \\
\hline (48) & 5HTTLPR & Fluoxetine & $\begin{array}{l}96 \text { depressed } \\
\text { patients }\end{array}$ & HAMD & $\begin{array}{l}\text { A single variation showed } \\
\text { a marginal association with } \\
\text { antidepressant response }\end{array}$ & $p=0.037$ \\
\hline (70) & 5HTTLPR & Sertraline & $\begin{array}{l}103 \text { depressed } \\
\text { patients and } 103 \\
\text { placebo controls }\end{array}$ & $\begin{array}{l}\text { HAMD and } \\
\text { CGI }\end{array}$ & $\begin{array}{l}\text { Short allele associated } \\
\text { with slower response }\end{array}$ & $p=0.01$ \\
\hline (7I) & 5HTTLPR & Citalopram & $\begin{array}{l}|3| \text { depressed } \\
\text { patients }\end{array}$ & HAMD & $\begin{array}{l}\text { s/s geneotype associated } \\
\text { with non remission }\end{array}$ & $p=0.006$ \\
\hline (72) & 5HTTLPR & $\begin{array}{l}\text { Fluoxetine or } \\
\text { nortriptyline }\end{array}$ & $\begin{array}{l}169 \text { depressed } \\
\text { patients }\end{array}$ & MADRS & $\begin{array}{l}<25 \text { years: no } \\
\text { association; }>25 \text { years: } \\
\text { HTTLPR s/s genotype } \\
\text { associated with a poorer } \\
\text { response to both } \\
\text { fluoxetine and } \\
\text { nortriptyline }\end{array}$ & $p=0.026$ \\
\hline
\end{tabular}


Table 6. Continued

\begin{tabular}{|c|c|c|c|c|c|c|}
\hline Reference & Gene & Drug & Sample & $\begin{array}{l}\text { Outcome } \\
\text { measure }\end{array}$ & Results & $p$-value \\
\hline (73) & 5HTTLPR & Fluoxetine & $\begin{array}{l}|2| \text { depressed } \\
\text { patients }\end{array}$ & HAMD & $\begin{array}{l}\text { I/I genotype shows a } \\
\text { better response }\end{array}$ & $p=0.013$ \\
\hline (74) & 5HTTLPR & Fluvoxamine & $\begin{array}{l}155 \text { depressed } \\
\text { patients }\end{array}$ & HAMD & $\begin{array}{l}\text { Long allele subjects were } \\
\text { more likely to respond }\end{array}$ & $p=0.029$ \\
\hline (75) & 5HTTLPR & SSRI, TCA & $\begin{array}{l}27 \text { bipolar patients } \\
\text { with at least one } \\
\text { manic episode } \\
\text { triggered by SSRIs } \\
\text { and } 29 \text { bipolar } \\
\text { patients who had } \\
\text { not }\end{array}$ & $\begin{array}{l}\text { Presence of } \\
\text { manic episode } \\
\text { induced by } \\
\text { serotonergic } \\
\text { antidepressant }\end{array}$ & $\begin{array}{l}\text { Patients with manic or } \\
\text { hypomanic episodes } \\
\text { induced by antidepressant } \\
\text { treatment had an excess } \\
\text { of short alleles }\end{array}$ & $p<0.001$ \\
\hline (76) & $5 H T T L P R$ & $\begin{array}{l}\text { Various } \\
\text { antidepressants }\end{array}$ & $\begin{array}{l}173 \text { depressed } \\
\text { patients }\end{array}$ & HAMD & $\begin{array}{l}\text { No association with } \\
\text { antidepressant response }\end{array}$ & Not significant \\
\hline (4) & $5 H T T L P R$ & Fluvoxamine & $\begin{array}{l}217 \text { depressed } \\
\text { patients }\end{array}$ & HAMD & $\begin{array}{l}\text { A/A genotype was } \\
\text { associated with slower } \\
\text { response in patients not } \\
\text { taking pindolol }\end{array}$ & $p=0.001$ \\
\hline (36) & $\begin{array}{l}\text { 5HTT Stin2 } \\
\text { 5HTTLPR }\end{array}$ & $\begin{array}{l}\text { Fluoxetine, } \\
\text { paroxetine }\end{array}$ & $\begin{array}{l}120 \text { patients and } \\
252 \text { controls }\end{array}$ & HAMD & $\begin{array}{l}\text { I/I in intron } 2 \text { was } \\
\text { associated with better } \\
\text { response to treatment s/s } \\
\text { genotype showed better } \\
\text { response }\end{array}$ & $\begin{array}{l}p<0.0001 \\
p=0.0074\end{array}$ \\
\hline
\end{tabular}

and abnormal hippocampal activation (associated with the $\mathrm{M}$ substitution), ${ }^{83}$ depressive disorder (although conflicting results have been found, mainly in non Caucasian samples), ${ }^{84}$ obsessive compulsive disorder ( $\mathrm{M}$ substitution represents a protective factor), ${ }^{85}$ anxiety ${ }^{86}$ restricting anorexia nervosa, low minimum body mass index, binge eating/ purging anorexia nervosa and bulimia nervosa ( $\mathrm{M}$ substitution is preferentially transmitted in cases), ${ }^{87}$ bipolar disorder and psychosis (Tables 7 and 8). ${ }^{92}$

\section{Conclusion}

The main conclusion of this review is that a pharmacogenetics-driven, personalised antidepressant treatment is still far from being achieved. Nonetheless, there is a set of candidate genes that have been shown to have a role in the response to antidepressant treatment, even though the results of the different studies have not been consistent. The main results demonstrating an association between antidepressant response and genetic background have involved the promoter of the serotonin transporter gene. In the Caucasian population, in the main, the long allele carriers show a better response to treatment, ${ }^{29}$ although a number of studies have failed to replicate this finding. The reasons for this failure can possibly be grouped into three main categories: 1) the biases that affect published results; 2) the characteristics of the 'drug response' as a trait; and 3) the intrinsic complexity of the genome. The biases that affect at least part of the published results are many-fold. The main ones are: 1) the definition of the significance level in association studies; 
Table 7. Relevant pharmacogenetics association studies that focused on serotonin receptor IA (5HTIA)

\begin{tabular}{|c|c|c|c|c|c|c|}
\hline Reference & Gene & Drug & Sample & $\begin{array}{l}\text { Outcome } \\
\text { measure }\end{array}$ & Results & $p$-value \\
\hline (44) & 5HTIA & SSRIs & $\begin{array}{l}\text { I33 } \\
\text { depressed } \\
\text { patients }\end{array}$ & HAMD & $\begin{array}{l}\text { No } \\
\text { association }\end{array}$ & $\begin{array}{l}\text { Not } \\
\text { significant }\end{array}$ \\
\hline$(46)$ & 5HTIA & Citalopram & $\begin{array}{l}130 \\
\text { depressed } \\
\text { patients }\end{array}$ & HAMD & $\begin{array}{l}\text { No } \\
\text { association }\end{array}$ & $p=0.009$ \\
\hline (88) & HTRIA & Fluvoxamine & $\begin{array}{l}\text { I5I major } \\
\text { depressed } \\
\text { and III } \\
\text { bipolar } \\
\text { patients }\end{array}$ & HAMD & $\begin{array}{l}\mathrm{C} / \mathrm{C} \\
\text { genotype } \\
\text { (C(-I0I9)G) } \\
\text { carriers } \\
\text { showed a } \\
\text { better } \\
\text { response to } \\
\text { fluvoxamine }\end{array}$ & $p=0.036$ \\
\hline (48) & 5HTIA & Fluoxetine & $\begin{array}{l}96 \text { subjects } \\
\text { with } \\
\text { unipolar } \\
\text { major } \\
\text { depression }\end{array}$ & HAMD & $\begin{array}{l}\text { No } \\
\text { association }\end{array}$ & $\begin{array}{l}\text { Not } \\
\text { significant }\end{array}$ \\
\hline (89) & HTRIA & Fluoxetine & $\begin{array}{l}222 \text { major } \\
\text { depressed } \\
\text { patients }\end{array}$ & HAMD & $\begin{array}{l}\text { Patients with } \\
\text { - I019C/C } \\
\text { genotype } \\
\text { associated } \\
\text { with better } \\
\text { response }\end{array}$ & $\begin{array}{l}p=0.001 \\
\text { (females) } \\
p=0.007 \\
\text { (males) }\end{array}$ \\
\hline (65) & HTRIA & Fluoxetine & $\begin{array}{l}224 \text { major } \\
\text { depressed } \\
\text { patients }\end{array}$ & HAMD & $\begin{array}{l}\text { HTRIA } \\
\text {-I0I9C/C } \\
\text { was found to } \\
\text { be associated } \\
\text { with a better } \\
\text { response }\end{array}$ & $p=0.009$ \\
\hline (20) & HTRIA & Fluvoxamine & $\begin{array}{l}100 \\
\text { depressed } \\
\text { outpatients }\end{array}$ & HAMD & $\begin{array}{l}\text { No } \\
\text { association }\end{array}$ & $\begin{array}{l}\text { Not } \\
\text { significant }\end{array}$ \\
\hline
\end{tabular}

Abbreviations: SSRI, selective serotonin reuptake inhibitor; HAMD, Hamilton Rating Scale for Depression; 5HTIA and HTRIA, serotonin receptor IA

2) sample size; and 3) stratification factors. The $p$-value that is chosen in most studies is set at $<0.05$; this is a frequent cause of false-positive findings and it is not sufficient for genetic analysis. ${ }^{93}$ Moreover, the $p$-value is strictly dependent on the study design; if the impact of a variation is determined by the hereditability of the association between genotype and phenotype, the minor allele frequency (MAF) of the variation will not profoundly affect the results of the study. When the strength of association between a mutation and a phenotype is expressed in terms of odds ratio (OR) or genotypic relative risk, however, the impact of MAF will be expected to be much higher (and in this case the selection of a more stringent $p$-value would be advised). Small sample sizes expose 
Table 8. Relevant pharmacogenetics association studies that focused on serotonin receptor $2 \mathrm{~A}(5 \mathrm{HT} 2 \mathrm{~A})$

\begin{tabular}{|c|c|c|c|c|c|c|}
\hline Reference & Gene & Drug & Sample & $\begin{array}{l}\text { Outcome } \\
\text { measure }\end{array}$ & Results & $p$-value \\
\hline (50) & $5 H T 2 A$ & Paroxetine & $\begin{array}{l}166 \\
\text { unipolar } \\
\text { depressed } \\
\text { patients }\end{array}$ & HAMD & $\begin{array}{l}\text { HTR2A C(I354)T } \\
\text { polymorphism } \\
\text { showed an } \\
\text { association with } \\
\text { remission and } \\
\text { response }\end{array}$ & $\begin{array}{l}p=0.002 \\
p=0.01\end{array}$ \\
\hline (90) & $5 H T 2 A$ & Citalopram & $\begin{array}{l}1953 \\
\text { depressed } \\
\text { patients } \\
(\text { STAR*D) }\end{array}$ & HAMD & $\begin{array}{l}\text { Positive association } \\
\text { with a marker in } \\
\text { the } 5 H T 2 A \text { gene }\end{array}$ & $\begin{array}{l}p \text { range } \\
1 \times 10^{-6} \text { to } \\
3.7 \times 10^{-5}\end{array}$ \\
\hline (48) & $5 H T 2 A$ & Fluoxetine & $\begin{array}{l}96 \text { subjects } \\
\text { with } \\
\text { unipolar } \\
\text { major } \\
\text { depression }\end{array}$ & HAMD & $\begin{array}{l}\text { Positive association } \\
\text { with three markers } \\
\text { in the } 5 H T 2 A \text { gene }\end{array}$ & $p=0.001-0.03$ \\
\hline (91) & $5 H T 2 A$ & $\begin{array}{l}\text { Paroxetine, } \\
\text { mirtazapine }\end{array}$ & $\begin{array}{l}246 \text { elderly } \\
\text { patients } \\
\text { with major } \\
\text { depression }\end{array}$ & $\begin{array}{l}\text { Discontinuation } \\
\text { rates }\end{array}$ & $\begin{array}{l}\text { The presence and } \\
\text { the severity of } \\
\text { paroxetine-induced } \\
\text { side effects were } \\
\text { strongly associated } \\
\text { with the } \mathrm{T}(\mathrm{I02}) \mathrm{C} \\
\mathrm{C} / \mathrm{C} \text { genotype }\end{array}$ & $p=0.001$ \\
\hline$(60)$ & $5 H T 2 A$ & $\begin{array}{l}\text { Fluvoxamine, } \\
\text { paroxetine }\end{array}$ & $\begin{array}{l}248 \text { bipolar } \\
\text { and } 195 \\
\text { depressed } \\
\text { patients }\end{array}$ & HAMD & $\begin{array}{l}\text { Marginal } \\
\text { association } \\
\text { between with } \\
\text { the } \mathrm{T}(102) \mathrm{C} \mathrm{C} \\
\text { allele and the } \\
\text { antidepressant } \\
\text { response }\end{array}$ & $p=0.001$ \\
\hline (76) & $5 H T 2 A$ & $\begin{array}{l}\text { Various } \\
\text { antidepressants }\end{array}$ & $\begin{array}{l}173 \\
\text { patients } \\
\text { with major } \\
\text { depression } \\
\text { and } 121 \\
\text { healthy } \\
\text { controls }\end{array}$ & HAMD & $\begin{array}{l}\text { Association } \\
\text { between } \mathrm{T}(\mathrm{I02}) \mathrm{C} \\
\mathrm{C} \text { allele and } \\
\text { antidepressant } \\
\text { response }\end{array}$ & $p=0.023$ \\
\hline (66) & $5 H T 2 A$ & $\begin{array}{l}\text { Fluoxetine and } \\
\text { paroxetine }\end{array}$ & $\begin{array}{l}100 \\
\text { depressed } \\
\text { patients }\end{array}$ & HAMD & $\begin{array}{l}\text { HTR2A: - I438G/G } \\
\text { associated with a } \\
\text { good response and } \\
\text { with nausea in } \\
\text { paroxetine-treated } \\
\text { patients }\end{array}$ & $\begin{array}{l}p=0.010 \\
p=0.013\end{array}$ \\
\hline
\end{tabular}

Abbreviation: HAMD, Hamilton Rating Scale for Depression 
studies to the risk of false-positive or false-negative findings, owing to the putative small impact of a variation on the definition of a phenotype. Sample sizes of hundreds or thousands of patients are required in order to detect a sufficient OR, but most of the published studies discussed here did not use such large sample sizes because of relevant stratification factors: ethnicity, socio-economic factors, psychological factors and environmental factors. ${ }^{94}$ In addition, it is difficult to define a psychiatric phenotype unambiguously. In this regard, the definition of biological endophenotypes will probably carry important benefits. Functional imaging studies provide a powerful tool to investigate this topic. Another relevant fault of published studies is the investigation of different variations within the same gene. In order to overcome this problem, a tag approach, together with an analysis of relevant mutations, should be used as a standard. Moreover, the lack of consistent replication of results is also dependent on the intrinsic complexity of the genome. A further difficulty comes from the scientific community's incomplete knowledge of what a gene is. A clear-cut way to figure it out is provided by the definition of a gene, which in early studies was 'everything upstream, up to and including the 50-most regulatory element, and everything downstream, up to and including the 30 -most regulatory element ${ }^{, 5}$ and is now referred to as: 'a union of genomic sequences encoding a coherent set of potentially overlapping functional products'. ${ }^{96}$ This is a broad definition, which loses the sense of a gene being a singular biological unit located in a defined position in the genome. Indeed, the definition of a 'candidate gene' is now expected to include parts of the genome that are scattered in different locations, definitively exceeding the limits of the $5^{\prime}$ - and $3^{\prime}$ - untranslated regions. Moreover, the presence of copy number variations and of a still poorly clarified epigenetic control exacerbates the complexity of the genome regulation that defines the response to a specific drug.

\section{References}

1. Maier, W. and Zobel, A. (2008), 'Contribution of allelic variations to the phenotype of response to antidepressants and antipsychotics', Eur. Arch. Psychiatry Clin. Neurosci. Vol. 258 (Suppl. 1), pp. 12-20.
2. Karasu, T.B., Gelenberg, A., Merriam, A. and Wang, P. (2000), 'American Psychiatric Association practice guideline for the treatment of patients with major depressive disorder', Am. J. Psychiatry Vol. 157, pp. $1-45$.

3. Trivedi, M.H., Rush, A.J., Wisniewski, S.R. et al. (2006), 'Evaluation of outcomes with citalopram for depression using measurement-based care in STAR*D: Implications for clinical practice', Am. J. Psychiatry Vol. 163, pp. $28-40$.

4. Serretti, A., Zanardi, A.R., Rossini, D. et al. (2001), 'Influence of tryptophan hydroxylase and serotonin transporter genes on fluvoxamine antidepressant activity', Mol. Psychiatry Vol. 6, pp. 586-592.

5. Dempfle, A., Scherag, A., Hein, R. et al. (2008), 'Gene-environment interactions for complex traits: Definitions, methodological requirements and challenges', Eur. J. Hum. Genet. Vol. 16, pp. 1164-1172.

6. Angst, J. (1964), 'Antidepressiver effect und genetische faktoren', Arzneimittelforschung Vol. 14, p. 500.

7. Pare, C.M., Rees, L. and Sainsbury, M.J. (1962), 'Differentiation of two genetically specific types of depression by the response to antidepressants', Lancet Vol. 2, pp. 1340-1343.

8. Pare, C.M. and Mack, J.W. (1971), 'Differentiation of two genetically specific types of depression by the response to antidepressant drugs', J. Med. Genet. Vol. 8, pp. 306-309

9. O’Reilly, R.L., Bogue, L. and Singh, S.M. (1994), 'Pharmacogenetic response to antidepressants in a multicase family with affective disorder', Biol. Psychiatry Vol. 36, pp. 467-471.

10. Franchini, L., Serretti, A., Gasperini, M. and Smeraldi, E. (1998), 'Familial concordance of fluvoxamine response as a tool for differentiating mood disorder pedigrees', J. Psychiatr. Res. Vol. 32, pp. 255-259.

11. Orsini, A. (1987), 'Antidepressant responses and segregation analyses in affective families', in: Racagni, G. and Smeraldi, E. (eds), 'Anxious Depression: Assessment and Treatment', Raven Press, New York, NY, USA.

12. Normann, C., Horn, M., Hummel, B. et al. (2004), 'Paroxetine in major depression: Correlating plasma concentrations and clinical response', Pharmacopsychiatry Vol. 37, pp. 123-126.

13. Drago, A., De Ponti, F., Boriani, G. et al. (2008), 'Strategy for a genetic assessment of antipsychotic and antidepressant-related proarrhythmia', Curr. Med. Chem. Vol. 15, pp. 2472-2517.

14. Peters, E.J., Slager, S.L., Kraft, J.B. et al. (2008), 'Pharmacokinetic genes do not influence response or tolerance to citalopram in the STAR*D sample', PLoS ONE, Vol. 3, p. e1872.

15. Kato, M., Fukuda, T., Serretti, A. et al. (2008), 'ABCB1 (MDR1) gene polymorphisms are associated with the clinical response to paroxetine in patients with major depressive disorder', Prog. Neuropsychopharmacol. Biol. Psychiatry Vol. 32, pp. 398-404

16. Uhr, M., Tontsch, A., Namendorf, C. et al. (2008), 'Polymorphisms in the drug transporter gene ABCB1 predict antidepressant treatment response in depression', Neuron. Vol. 57, pp. 203-209.

17. David, S.P., Brown, R.A., Papandonatos, G.D. et al. (2007), 'Pharmacogenetic clinical trial of sustained-release bupropion for smoking cessation', Nicotine Tob. Res. Vol. 9, pp. 821-833.

18. Koski, A., Sistonen, J., Ojanpera, I. et al. (2006), 'CYP2D6 and CYP2C19 genotypes and amitriptyline metabolite ratios in a series of medicolegal autopsies', Forensic Sci. Int. Vol. 158, pp. 177-183.

19. Shams, M.E., Arneth, B., Hiemke, C. et al. (2006), 'CYP2D6 polymorphism and clinical effect of the antidepressant venlafaxine', J. Clin. Pharm. Ther. Vol. 31, pp. 493-502.

20. Suzuki, Y., Sawamura, K. and Someya, T. (2006), 'Polymorphisms in the 5-hydroxytryptamine 2A receptor and cytochrome P4502D6 genes synergistically predict fluvoxamine-induced side effects in Japanese depressed patients', Neuropsychopharmacology Vol. 31, pp. 825-831.

21. Grasmader, K., Verwohlt, P.L., Rietschel, M. et al. (2004), 'Impact of polymorphisms of cytochrome-P450 isoenzymes 2C9, 2C19 and 2D6 on plasma concentrations and clinical effects of antidepressants in a naturalistic clinical setting', Eur. J. Clin. Pharmacol. Vol. 60, pp. 329-336.

22. Rau, T., Wohlleben, G., Wuttke, H. et al. (2004), 'CYP2D6 genotype: Impact on adverse effects and nonresponse during treatment with antidepressants-a pilot study', Clin. Pharmacol. Ther. Vol. 75, pp. 386-393. 
23. Roberts, R.L., Joyce, P.R., Mulder, R.T. et al. (2002), 'A common $\mathrm{P}$-glycoprotein polymorphism is associated with nortriptyline-induced postural hypotension in patients treated for major depression', Pharmacogenomics J. Vol. 2, pp. 191-196.

24. Hu, J., Redden, D.T., Berrettini, W.H. et al. (2006), 'No evidence for a major role of polymorphisms during bupropion treatment', Obesity (Silver Spring) Vol. 14, pp. 1863-1867.

25. Arias, B., Serretti, A., Lorenzi, C. et al. (2006), 'Analysis of COMT gene (Val 158 Met polymorphism) in the clinical response to SSRIs in depressive patients of European origin', J. Affect. Disord. Vol. 90, pp. 251-256.

26. Szegedi, A., Rujescu, D., Tadic, A. et al. (2005), 'The catechol-O-methyltransferase Val108/158Met polymorphism affects short-term treatment response to mirtazapine, but not to paroxetine in major depression', Pharmacogenomics J. Vol. 5, pp. 49-53.

27. Moret, C. and Briley, M. (1990), 'Serotonin autoreceptor subsensitivity and antidepressant activity', Eur. J. Pharmacol. Vol. 180, pp. 351-356.

28. Meyer, J.H., Kapur, S., Eisfeld, B. et al. (2001), 'The effect of paroxetine on 5-HT(2A) receptors in depression: An $[(18) \mathrm{F}]$ setoperone PET imaging study', Am. J. Psychiatry Vol. 158, pp. 78-85.

29. Serretti, A., Kato, M., De Ronchi, D. and Kinoshita, T. (2007), 'Meta-analysis of serotonin transporter gene promoter polymorphism (5-HTTLPR) association with selective serotonin reuptake inhibitor efficacy in depressed patients', Mol. Psychiatry Vol. 12, pp. 247-257.

30. Oberlander, T.F., Bonaguro, R.J., Misri, S. et al. (2008), 'Infant serotonin transporter (SLC6A4) promoter genotype is associated with adverse neonatal outcomes after prenatal exposure to serotonin reuptake inhibitor medications', Mol. Psychiatry Vol. 13, pp. 65-73.

31. Benedetti, F., Barbini, B., Bernasconi, A. et al. (2008), 'Lithium overcomes the influence of 5-HTTLPR gene polymorphism on antidepressant response to sleep deprivation', J. Clin. Psychopharmacol. Vol. 28, pp. 249-251.

32. Carli, M. and Reader, T.A. (1997), 'Regulation of central serotonin transporters by chronic lithium: An autoradiographic study', Synapse Vol. 27, pp. 83-89.

33. Perez, V., Gilaberte, I., Faries, D. et al. (1997), 'Randomised, doubleblind, placebo-controlled trial of pindolol in combination with fluoxetine antidepressant treatment', Lancet Vol. 349, pp. 1594-1597.

34. Smeraldi, E., Serretti, A., Artioli, P. et al. (2006), 'Serotonin transporter gene-linked polymorphic region: Possible pharmacogenetic implications of rare variants', Psychiatr. Genet. Vol. 16, pp. 153-158.

35. Hu, X.Z., Rush, A.J., Charney, D. et al. (2007), 'Association between a functional serotonin transporter promoter polymorphism and citalopram treatment in adult outpatients with major depression', Arch. Gen. Psychiatry Vol. 64, pp. 783-792.

36. Kim, D.K., Lim, S.W., Lee, S. et al. (2000), 'Serotonin transporter gene polymorphism and antidepressant response', Neuroreport Vol. 11, pp. 215-219.

37. Smits, K.M., Smits, L.J., Peeters, F.P. et al. (2008), 'The influence of 5 -HTTLPR and STin2 polymorphisms in the serotonin transporter gene on treatment effect of selective serotonin reuptake inhibitors in depressive patients', Psychiatr. Genet. Vol. 18, pp. 184-190.

38. Drago, A., De Ronchi, D. and Serretti, A. (2008), '5-HT1A gene variants and psychiatric disorders: A review of current literature and selection of SNPs for future studies', Int. J. Neuropsychopharmacol. Vol. 11, pp. $701-721$.

39. Serretti, A., Drago, A. and De Ronchi, D. (2007), 'HTR2A gene variants and psychiatric disorders: A review of current literature and selection of SNPs for future studies', Curr. Med. Chem. Vol. 14, pp. 2053-2069.

40. Pejchal, T., Foley, M.A., Kosofsky, B.E. and Waeber, C. (2002), 'Chronic fluoxetine treatment selectively uncouples raphe 5-HT(1A) receptors as measured by [(35)S]-GTP gamma S autoradiography', Br. J. Pharmacol. Vol. 135, pp. 1115-1122.

41. Moulin-Sallanon, M., Charnay, Y., Ginovart, N. et al. (2008), 'Acute and chronic effects of citalopram on 5-HT(1A) receptor-labeling by $[(18) F] M P P F$ and -coupling to receptors-G proteins', Synapse Vol. 63, pp. 106-116.
42. Lemonde, S., Turecki, G., Bakish, D. et al. (2003), 'Impaired transrepression at a 5-hydroxytryptamine $1 \mathrm{~A}$ receptor gene polymorphism associated with major depression and suicide', J. Neurosci. Vol. 23, pp. 8788-8799.

43. Parsey, R.V., Olvet, D.M., Oquendo, M.A. et al. (2006), 'Higher 5-HT1A receptor binding potential during a major depressive episode predicts poor treatment response: Preliminary data from a naturalistic study', Neuropsychopharmacology Vol. 31, pp. 1745-1749.

44. Levin, G.M., Bowles, T.M., Ehret, M.J. et al. (2007), 'Assessment of human serotonin 1A receptor polymorphisms and SSRI responsiveness', Mol. Diagn. Ther. Vol. 11, pp. 155-160.

45. Uher, R. (2008), 'The implications of gene-environment interactions in depression: Will cause inform cure?', Mol. Psychiatry Vol. 13, pp. 1070-1078.

46. Arias, B., Catalan, R., Gasto, C. et al. (2005), 'Evidence for a combined genetic effect of the 5-HT1A receptor and serotonin transporter genes in the clinical outcome of major depressive patients treated with citalopram', J. Psychopharmacol. Vol. 19, pp. 166-172.

47. Sullivan, P.F. (2007), 'Spurious genetic associations', Biol. Psychiatry Vol. 61, pp. 1121-1126.

48. Peters, E.J., Slager, S.L., McGrath, P.J. et al. (2004), 'Investigation of serotonin-related genes in antidepressant response', Mol. Psychiatry Vol. 9, pp. 879-889.

49. Spurlock, G., Heils, A., Holmans, P. et al. (1998), 'A family based association study of T102C polymorphism in 5HT2A and schizophrenia plus identification of new polymorphisms in the promoter', Mol. Psychiatry Vol. 3, pp. 42-49.

50. Wilkie, M.J., Smith, G., Day, R.K. et al. (2009), 'Polymorphisms in the SLC6A4 and HTR2A genes influence treatment outcome following antidepressant therapy', Pharmacogenomics J. Vol. 9, pp. 61-70.

51. Tanaka, M., Kobayashi, D., Murakami, Y. et al. (2008), 'Genetic polymorphisms in the 5-hydroxytryptamine type 3B receptor gene and paroxetine-induced nausea', Int. J. Neuropsychopharmacol. Vol. 11, pp. $261-267$.

52. Stahl, S. (1994), "5HT1A receptors and pharmacotherapy. Is serotonin receptor down-regulation linked to the mechanism of action of antidepressant drugs?', Psychopharmacol. Bull. Vol. 30, pp. 39-43.

53. Nakamura, K., Sugawara, Y., Sawabe, K. et al. (2006), 'Late developmental stage-specific role of tryptophan hydroxylase 1 in brain serotonin levels', J. Neurosci. Vol. 26, pp. 530-534.

54. Jonsson, E.G., Goldman, D., Spurlock, G. et al. (1997), 'Tryptophan hydroxylase and catechol-O-methyltransferase gene polymorphisms: Relationships to monoamine metabolite concentrations in CSF of healthy volunteers', Eur. Arch. Psychiatr. Clin. Neurosci. Vol. 247, pp. 297-302.

55. Ham, B.J., Lee, B.C., Paik, J.W. et al. (2007), 'Association between the tryptophan hydroxylase-1 gene A218C polymorphism and citalopram antidepressant response in a Korean population', Prog. Neuropsychopharmacol. Biol. Psychiatry Vol. 31, pp. 104-107.

56. Ham, B., Lee, M., Lee, H. et al. (2005), 'No association between the tryptophan hydroxylase gene polymorphism and major depressive disorders and antidepressant response in a Korean population', Psychiatr. Genet. Vol. 15, pp. 229-301.

57. Serretti, A., Cusin, C., Rossini, D. et al. (2004), 'Further evidence of a combined effect of SERTPR and TPH on SSRIs response in mood disorders', Am. J. Med. Genet. B Neuropsychiatr. Genet. Vol. 129, pp. 36-40.

58. Serretti, A., Zanardi, R., Cusin, C. et al. (2001), 'Tryptophan hydroxylase gene associated with paroxetine antidepressant activity', Eur. Neuropsychopharmacol. Vol. 11, pp. 375-380.

59. Serretti, A., Cristina, S., Lilli, R. et al. (2002), 'Family-based association study of 5-HTTLPR, TPH, MAO-A, and DRD4 polymorphisms in mood disorders', Am. J. Med. Genet. Vol. 114, pp. 361-369.

60. Cusin, C., Serretti, A., Zanardi, R. et al. (2002), 'Influence of monoamine oxydase $\mathrm{A}$ and serotonin receptor $2 \mathrm{~A}$ polymorphisms in SSRIs antidepressant activity', Int. J. Neuropsychopharmacol. Vol. 5, pp. $27-35$ 
61. Lotrich, FE., Pollock, B.G., Kirshner, M. et al. (2008), 'Serotonin transporter genotype interacts with paroxetine plasma levels to influence depression treatment response in geriatric patients', J. Psychiatry Neurosci. Vol. 33, pp. 123-130.

62. Kirchheiner, J., Nickchen, K., Sasse, J. et al. (2007), 'A 40-basepair VNTR polymorphism in the dopamine transporter (DAT1) gene and the rapid response to antidepressant treatment', Pharmacogenomics J. Vol. 7, pp. $48-55$.

63. Kim, H., Lim, S.W., Kim, S. et al. (2006), 'Monoamine transporter gene polymorphisms and antidepressant response in Koreans with late-life depression', JAMA Vol. 296, pp. 1609-1618.

64. Popp, J., Leucht, S., Heres, S. and Steimer, W. (2006), 'Serotonin transporter polymorphisms and side effects in antidepressant therapy $-\mathrm{A}$ pilot study', Pharmacogenomics Vol. 7, pp. 159-166.

65. Hong, C.J., Chen, T.J., Yu, Y.W. and Tsai, S.J. (2006), 'Response to fluoxetine and serotonin 1A receptor (C-1019G) polymorphism in Taiwan Chinese major depressive disorder', Pharmacogenomics J. Vol. 6, pp. 27-33.

66. Kato, M., Fukuda, T., Wakeno, M. et al. (2006), 'Effects of the serotonin type $2 \mathrm{~A}, 3 \mathrm{~A}$ and $3 \mathrm{~B}$ receptor and the serotonin transporter genes on paroxetine and fluvoxamine efficacy and adverse drug reactions in depressed Japanese patients', Neuropsychobiology Vol. 53, pp. 186-195.

67. Serretti, A., Zanardi, R., Franchini, L. et al. (2004), 'Pharmacogenetics of selective serotonin reuptake inhibitor response: A 6-month follow-up', Pharmacogenetics Vol. 14, pp. 607-613.

68. Yoshida, K., Takahashi, H., Higuchi, H. et al. (2004), 'Prediction of antidepressant response to milnacipran by norepinephrine transporter gene polymorphisms', Am. J. Psychiatry Vol. 161, pp. 1575-1580.

69. Lee, M.S., Lee, H.Y., Lee, H.J. and Ryu, S.H. (2004), 'Serotonin transporter promoter gene polymorphism and long-term outcome of antidepressant treatment', Psychiatr. Genet. Vol. 14, pp. 111-115.

70. Durham, L.K., Webb, S.M., Milos, P.M. et al. (2004), 'The serotonin transporter polymorphism, 5HTTLPR, is associated with a faster response time to sertraline in an elderly population with major depressive disorder', Psychopharmacology (Berl.) Vol. 174, pp. 525-529.

71. Arias, B., Catalan, R., Gasto, C. et al. (2003), '5-HTTLPR polymorphism of the serotonin transporter gene predicts non-remission in major depression patients treated with citalopram in a 12 -weeks follow up study', J. Clin. Psychopharmacol. Vol. 23, pp. 563-567.

72. Joyce, P.R., Mulder, R.T., Luty, S.E. et al. (2003), 'Age-dependent antidepressant pharmacogenomics: Polymorphisms of the serotonin transporter and $G$ protein beta3 subunit as predictors of response to fluoxetine and nortriptyline', Int. J. Neuropsychopharmacol. Vol. 6, pp. 339-346.

73. Yu, Y.W., Tsai, S.J., Chen, T.J. et al. (2002), 'Association study of the serotonin transporter promoter polymorphism and symptomatology and antidepressant response in major depressive disorders', Mol. Psychiatry Vol. 7, pp. 1115-1119.

74. Zanardi, R., Serretti, A., Rossini, D. et al. (2001), 'Factors affecting fluvoxamine antidepressant activity: Influence of pindolol and 5-HTTLPR in delusional and nondelusional depression', Biol. Psychiatry Vol. 50, pp. $323-330$.

75. Mundo, E., Walker, M., Cate, T. et al. (2001), 'The role of serotonin transporter protein gene in antidepressant-induced mania in bipolar disorder', Arch. Gen. Psychiatry Vol. 58, pp. 539-544.

76. Minov, C., Baghai, T.C., Schule, C. et al. (2001), 'Serotonin-2A-receptor and -transporter polymorphisms: lack of association in patients with major depression', Neurosci. Lett. Vol. 303, pp. 119-122.

77. Shishkina, G.T., Kalinina, T.S. and Dygalo, N.N. (2007), 'Up-regulation of tryptophan hydroxylase-2 mRNA in the rat brain by chronic fluoxetine treatment correlates with its antidepressant effect', Neuroscience Vol. 150, pp. 404-412.

78. Siffert, W., Rosskopf, D., Siffert, G. et al. (1998), 'Association of a human G-protein beta3 subunit variant with hypertension', Nat. Genet. Vol. 18 , pp. $45-48$.
79. Holsboer, F. (2000), 'The corticosteroid receptor hypothesis of depression', Neuropsychopharmacology Vol. 23, pp. 477-501.

80. Binder, E., Salyakina, D., Lichtner, P. et al. (2004), 'Polymorphisms in FKBP5 are associated with increased recurrence of depressive episodes and rapid response to antidepressant treatment.' Nat. Genet. Vol. 36, pp. $1319-1325$.

81. Tsai, S.J., Hong, C.J., Chen, T.J. and Yu, Y.W. (2007), 'Lack of supporting evidence for a genetic association of the FKBP5 polymorphism and response to antidepressant treatment', Am. J. Med. Genet. B Neuropsychiatr. Genet. Vol. 144B, pp. 1097-1098.

82. Liu, Z., Zhu, F., Wang, G. et al. (2007), 'Association study of corticotropin-releasing hormone receptor1 gene polymorphisms and antidepressant response in major depressive disorders', Neurosci. Lett. Vol. 414, pp. $155-158$.

83. Egan, M.F, Kojima, M., Callicott, J.H. et al. (2003), 'The BDNF val66met polymorphism affects activity-dependent secretion of BDNF and human memory and hippocampal function', Cell Vol. 112, pp. 257-269.

84. Gratacos, M., Soria, V., Urretavizcaya, M. et al. (2008), 'A brain-derived neurotrophic factor (BDNF) haplotype is associated with antidepressant treatment outcome in mood disorders', Pharmacogenomics J. Vol. 8, pp. 101-112.

85. Hall, D., Dhilla, A., Charalambous, A. et al. (2003), 'Sequence variants of the brain-derived neurotrophic factor (BDNF) gene are strongly associated with obsessive-compulsive disorder', Am. J. Hum. Genet. Vol. 73, pp. $370-376$.

86. Hunnerkopf, R., Strobel, A., Gutknecht, L. et al. (2007), 'Interaction between BDNF Val66Met and dopamine transporter gene variation influences anxiety-related traits', Neuropsychopharmacology Vol. 32, pp. $2552-2560$

87. Ribases, M., Gratacos, M., Armengol, L. et al. (2003), 'Met66 in the brain-derived neurotrophic factor (BDNF) precursor is associated with anorexia nervosa restrictive type', Mol. Psychiatry Vol. 8, pp. 745-751.

88. Serretti, A., Artioli, P., Lorenzi, C. et al. (2004), 'The C(-1019)G polymorphism of the 5-HT1A gene promoter and antidepressant response in mood disorders: Preliminary findings', Int. J. Neuropsychopharmacol. Vol. 7, pp. 453-460.

89. Yu, Y.W., Tsai, S.J., Liou, Y.J. et al. (2006), 'Association study of two serotonin $1 \mathrm{~A}$ receptor gene polymorphisms and fluoxetine treatment response in Chinese major depressive disorders', Eur. Neuropsychopharmacol. Vol. 16, pp. 498-503.

90. McMahon, FJ., Buervenich, S., Charney, D. et al. (2006), "Variation in the gene encoding the serotonin $2 \mathrm{~A}$ receptor is associated with outcome of antidepressant treatment', Am. J. Hum. Genet. Vol. 78, pp. 804-814.

91. Murphy, G., Hollander, S., Rodrigues, H. and Schatzberg, A. (2003), 'Effects of the serotonin transporter promoter polymorphism on paroxetine and mirtazapine efficacy and side effects in geriatric major depression', in: Hospital, T.Z.H (ed), 'Pharmacogenetics in Psychiatry Meeting Vol. 1', New York, NY, p. green tab.

92. Rosa, A., Cuesta, M.J., Fatjo-Vilas, M. et al. (2006), 'The Val66Met polymorphism of the brain-derived neurotrophic factor gene is associated with risk for psychosis: Evidence from a family-based association study', Am. J. Med. Genet. B Neuropsychiatr. Genet. Vol. 141B, pp. 135-138.

93. Nebert, D.W., Zhang, G. and Vesell, E.S. (2008), 'From human genetics and genomics to pharmacogenetics and pharmacogenomics: Past lessons, future directions', Drug Metab. Rev. Vol. 40, pp. 187-224.

94. Serretti, A., Kato, M. and Kennedy, L.J. (2008), 'Pharmacogenetic studies in depression: A proposal for methodologic guidelines', Pharmacogenomics J. Vol. 8, pp. 90-100.

95. Nebert, D.W. (2000), 'Suggestions for the nomenclature of human alleles: Relevance to ecogenetics, pharmacogenetics and molecular epidemiology', Pharmacogenetics Vol. 10, pp. 279-290.

96. Gerstein, M.B., Bruce, C., Rozowsky, J.S. et al. (2007), 'What is a gene, post-ENCODE? History and updated definition', Genome Res. Vol. 17, pp. 669-681. 